\title{
Ewakuacja Polaków z Archangielska I MurmańSKa w 1919 ROKU
}

Słow a klucz o we : wojsko polskie w Rosji, Gdańsk, Armia Polska we Francji, Batalion Murmański, reemigracja, historia polityczna Polski

Ke y w ord s: Polish army in Russia, Gdańsk, Polish Army in France, Murmansk Battalion, reemigration, political history of Poland

\section{ABSTRACT}

In the three shipwrecked transports by sea in 1919, Polish soldiers and civilian refugees from Archangelsk and Murmansk - ships "Stephen”, "Caritza” and „Helena” were evacuated at least 1093 people, including 369 officers and privates. Considering that Poles left the area of northern Russia also in small groups or individually, it can be estimated that the total number of Poles evacuated in 1919 from that region exceeded 1.5 thousand. people. For comparison, evacuation by sea to Gdansk Poles from the Far East in 1920 ships "Gweneth”, „Yaroslavl”, „Voronezh” and „Brandenburg” - covered a total of nearly 3.2 thousand. people, including 1744 officers and privates. Despite the difficulties arising from the limitation of Polish laws, the port of Gdansk in 1919-1920 was the most convenient place for receiving ships with Poles returning to the country. The dimensions of the described phenomenon are evidenced by data concerning the period from August 1919 to April 12, 1920 - in Gdańsk, 9,981 persons returning by ship to Poland were admitted at that time. Although another ship „Helena” with Polish soldiers evacuated from Arkhangelsk finished their flight not in Gdansk but in Szczecin, however, in 1920, the above-mentioned, four organized sea transports with reemigrants from the Far East came to Gdańsk. After the end of the First World War, Gdańsk fulfilled - to a limited extent - the role of the Polish "window to the world", although it is worth noting that the implementation of the return of Polish soldiers from distant parts by the city be- 
ing subject to a sharp Polish-German dispute was not used by the Polish authorities to strengthen de facto Polish position in the Baltic Sea port.

T Tprawdzie Polacy - pozbawieni własnego państwa - odegrali niewielką rolę w działaniach wojennych w trakcie I wojny światowej (1914-1918), niemniej jednak gdy zaistniały sprzyjające warunki, tworzyli własne formacje wojskowe, których celem miała być walka z państwami zaborczymi. Niezależnie od podziału na zwolenników walki z Niemcami lub z Rosją, jedni i drudzy, jak skonstatował Władysław Konopczyński: „Budzili Polskę i Europę (...) na ogół działając bez porozumienia, często w głębokim nieporozumieniu"1. Dla zwyczajnych żołnierzy spory orientacyjne nierzadko nie miały większego znaczenia, a liczył się sam fakt służby w wojsku polskim. Polskie oddziały powstawały nawet $w$ miejscach odległych od ziem historycznie i etnograficznie polskich, w tym na rozległym terytorium Rosji, gdzie przebywali Polacy przesiedleni na Syberię, jeńcy wojenni, a w okresie wojny domowej w Rosji uciekinierzy z terenów objętych walkami.

Po wybuchu rewolucji lutowej w Rosji, 22 czerwca 1917 r., na zjeździe Związku Wojskowych Polaków w Rosji został wyłoniony Naczelny Polski Komitet Wojskowy z prezesem Władysławem Raczkiewiczem - stanowiący namiastkę polskiej reprezentacji politycznej na obszarze Rosji. Pod auspicjami Komitetu zaczęły powstawać polskie siły zbrojne (w sile trzech korpusów), mające walczyć u boku sprzymierzonych, jednakże w dalszym ciągu pod dowództwem Armii Rosyjskiej. Przewrót bolszewicki w listopadzie 1917 r. skomplikował sytuację i ostatecznie polskie formacje uległy dezintegracji. I Korpus gen. Dowbora-Muśnickiego na Białorusi w maju 1918 r. został rozbrojony przez Niemców, a żołnierze wrócili do Polski, gdzie odegrali znaczącą rolę w tworzeniu wojska polskiego w Wielkopolsce. Podobny los spotkał II Korpus gen. Sylwestra Stankiewicza (gen. Józefa Hallera) tworzony w Besarabii, który skapitulował po bitwie pod Kaniowem 11 maja tegoż roku. Natomiast III Korpus gen. Eugeniusza de Henninga-Michaelisa, powstający na terytorium Ukrainy, został w nocy z 9 na 10 czerwca 1918 r. rozbrojony przez wojska austriackie.

W tej sytuacji dowodzący wojskami polskimi w Rosji gen. Józef Haller zawarł w czerwcu 1918 r. umowę z koalicjantami, na mocy której na terytorium

1 W. Konopczyński, Historia polityczna Polski 1914-1939, Warszawa 1995, s. 31. 
Rosji nieopanowanym przez bolszewików zaczęto formować nowe jednostki wojskowe, wchodzące w skład tworzonej we Francji Armii Polskiej i podporządkowane politycznie Komitetowi Narodowemu Polskiemu, uznawanemu przez Ententę za oficjalną reprezentację Polski². Na miejsce formowania nowych oddziałów wybrano początkowo Powołże (następnie Syberię), gdzie powstała 5 Dywizja Strzelców Polskich dowodzona przez płk. Kazimierza Rumszę oraz północne kresy Rosji, gdzie miała powstać 4 Dywizja Strzelców Polskich. Jednakże trudności z przedostaniem się Polaków na Północ przez rozległe obszary opanowane przez bolszewików spowodowały, że ostatecznie wyznaczono nowe miejsce koncentracji na Kubaniu, gdzie sformowaną Dywizją dowodził płk Franciszek Zieliński, zastąpiony później przez gen. Lucjana Żeligowskiego, stojącego na czele wszystkich polskich formacji wojskowych na Wschodzie, a następnie bezpośrednio dowodzącego 4 Dywizją, która na wiosnę 1919 r. - po walkach z bolszewikami - przedostała się do Polski przez terytorium Rumunii. Z kolei 5 Dywizja w trakcie ewakuacji na Daleki Wschód koleją transsyberyjską 23 grudnia 1919 r. stoczyła z bolszewikami bitwę o stację kolejową Tajga i niedługo potem skapitulowała 10 stycznia 1920 r. pod stacją Klukwiennaja. Jedynie część żołnierzy pod dowództwem płk. Rumszy zdołała przedostać się na wschód do Władywostoku oraz Harbinu. Stamtąd żołnierze wraz z towarzyszącymi im cywilnymi uchodźcami przedostali się drogą morską na pokładzie statków do Polski.

\section{Żołnierze polscy na Półwyspie Kolskim i Archangielsku}

Zgodnie z „L'instructionprovisoire”, podpisaną 28 czerwca 1918 r. przez gen. Hallera - zmierzającego z Moskwy do Paryża trasą prowadzącą przez Murmańsk - a następnie zatwierdzoną 1 lipca przez angielskiego dowódcę frontu koalicyjnego gen. Fredericka CuthbertaPoole’a, oddział polski na północy

2 Utworzenie armii polskiej we Francji zapowiedział dekret prezydenta Francji Raymonda Poincaré'a z 4 VI 1917. W czerwcu 1918 r. Francuzi planowali utworzenie w Rosji punktów zbornych („des bureaux de recruitementpourl'arméepolonaises en France”), usytuowanych w Moskwie, Murmańsku, Harbinie i Władywostoku. Pismo dyrektora politycznego Quaid'OrsayPierre de Margerie do konsula generalnego Francji w Warszawie przebywającego czasowo w Moskwie Veltena, Paris 24 VI 1918, za: J. Pajewski, Odbudowa państwa polskiego 1914-1918, Warszawa 1985, s. 255-256. 
Rosji miał być częścią składową Armii Polskiej we Francji. Wypływając 3 lipca brytyjskim niszczycielem z Murmańska do Paryża, gen. Haller powierzył płk. Stanisławowi Machcewiczowi dowództwo nad tworzącym się wojskiem polskim. Polacy napływający do punktów zbornych w Koli i Murmańsku zostali uformowani w oddział w Koli, składający się z 1 kompanii strzelców (liczącej 21 sierpnia 4 oficerów i 68 żołnierzy) oraz Legii Oficerskiej (liczącej 21 lipca 77 osób) z plutonem karabinów maszynowych i baterią artyleryjską ${ }^{3}$. Ponadto Polacy utworzyli mniejszą jednostkę w Archangielsku, oddział dwiński i oddział oneski. Do końca 1918 r. wszystkie rozproszone formacje skupiono w Archangielsku, natomiast nadliczbowi oficerowie, nieposiadający przydziałów służbowych, zostali wysłani do Francji, gdzie wojsko polskie borykało się z niedoborem kadry oficerskiej.

Przeniesienie wojsk stacjonujących w Koli do Archangielska miało ścisły związek z ofensywą wojsk Koalicji, skierowaną przeciwko bolszewikom. 24 lipca bateria artylerii, składająca się z 4 oficerów i 42 oficerów pełniących obowiązki żołnierzy, została wysłana z Koli do Murmańska, a następnie w dniach 31 lipca-3 sierpnia odbyła podróż morską statkiem „Stephen” do Archangielska ${ }^{4}$. Natomiast 18 października Kolę opuściła kompania strzelców, która 21 października wypłynęła z portu w Murmańsku na pokładzie statku „Asturian” i po dwóch dniach przybyła do portu w Archangielsku (w samym mieście żołnierze pojawili się dopiero 28 października) ${ }^{5}$. Wojsko polskie w Archangielsku zostało podzielone na Szkołę Oficerską, skupiającą wszystkich nadetatowych oficerów oraz batalion strzelców. W dniu 1 listopada w szkole znajdowało się 67 oficerów, w batalionie 15 oficerów i 122 szeregowych, natomiast oddział sztabowy liczył 16 oficerów i 16 szeregowych, czyli łącznie w listopadzie 1918 r. w Archangielsku służyło 236 żołnierzy. Z kolei w dniu 1 grudnia 1918 r. batalion liczył 90 oficerów, 33 podoficerów i 176 żołnierzy.

${ }^{3}$ H. Bagiński, Wojsko Polskie na Wschodzie 1914-1920, Warszawa 1921, s. 444-445, 450-451.

„Na kolejach północnej Europy można było zauważyć licznych cudzoziemców o wojskowym wyglądzie, jadących pod ocean Lodowaty, wychudzonych i wybladłych, lecz z żarem zapału i odwagi w oczach. Byli to żołnierze polscy, oficerowie i szeregowcy, którzy (...) posiadając papiery francuskie, dążyli na okupowany przez Koalicję Murman (...)", Ibidem, s. 447.

${ }^{4}$ H. Bagiński, dz.cyt., s. 451, 456, 458.

5 Tamże, s. 464. 
Reasumując, w sumie niewielkie wojsko polskie liczyło pod koniec 1918 r. około 300 żołnierzy. Jeden z pamiętnikarzy utrwalił dla potomności następującą jego charakterystykę: „Karabiny mieliśmy rosyjskie i japońskie, żołd - francuski, mundury - angielskie, orzełki i serca polskie. I polską komendę"6.

Po wyjeździe do Francji płk. Machcewicza 29 października dowódcą Batalionu Murmańskiego został mjr Julian Skokowski (szefem sztabu był kpt. Bogusław Szul-Skjöldkrona). Funkcję przedstawiciela wojskowego Polski w północnej Rosji pełnił ppłk Stanisław Dowoyno-Sołłohub. Wszyscy żołnierze przebywający w Archangielsku złożyli 10 grudnia przysięgę na wierność narodowi polskiemu, według roty ustalonej przez naczelne dowództwo Wojsk Polskich we Francji.

Przedstawiciele kadry oficerskiej systematycznie opuszczali Rosję, kierując się do Francji. Przykładowo, w dniu 26 listopada do Francji wyjechali m.in. ppłk Kubiak, kpt. Lipski i ppor. Benedykt ${ }^{7}$. W dniu 11 grudnia gen. Haller wydał rozkaz wysłania całego oddziału polskiego do Francji celem połączenia go z formowaną tam „Błękitną Armią”, jednak ostatecznie została odesłana jedynie kolejna partia nadliczbowych oficerów i podchorążych (aspirantów) tworzących Legię Oficerską. Oficerowie bez przydziałów (70 oficerów i 7 podchorążych) wyjechali w grudniu z Archangielska do Murmańska, gdzie spędzili miesiąc, po czym 16 stycznia 1919 r. na pokładzie statku „Stephen” odbyli podróż do Newcastle w Szkocji. Wśród ewakuowanych znajdowali się m.in.: wybitny pisarz ppor. Eugeniusz Małaczewski (chorujący na gruźlicę), wybitny dziennikarz i polityk pchor. Stanisław Strzetelski, por. Zdzisław Chrząstowski. Trasa dalszej podróży prowadziła do Londynu, a stamtąd Murmańczycy przepłynęli przez kanał La Manche do Hawrü

Po odesłaniu oficerów i podchorążych z Archangielska do Francji oraz powrocie w dniu 22 grudnia niewielkiego oddziału dwińskiego tzw. „Lwów Pół-

${ }^{6}$ Żotnierz polski na Murmanie: jednodniówka wydana z okazji pierwszego zjazdu murmańczyków: 1919 15/XII 1929, Warszawa 1929, s. 23-36, 37-38, 43-44; H. Bagiński, dz.cyt., s. 464-467; Z. Chrząstowski, Legenda murmańska, Łomianki 2014, s. 18. W kwietniu 1919 r. żołnierze polscy otrzymali: „niebieskie mundury francuskie i niebieskie rogatywki, wydane przez Francuzów, na wzór polskich dywizji, formowanych we Francji, z tą jedynie różnicą, że na ubraniu i czapce noszono białe wypustki dla upamiętnienia walk pod biegunem.", H. Bagiński, dz.cyt., s. 477.

7 Tamże, s. 467.

8 Tamże, s. 451, 476; Z. Chrząstowski, dz.cyt., s. 191, 195, 202. 
nocy" z frontu wojsko polskie w Archangielsku tworzyła Kompania Kadrowa pozostająca tymczasowo w mieście i mająca docelowo uformować drugą kompanię strzelców oraz (pierwsza) kompania strzelców, która w okresie od 16 grudnia 1918 r. do 18 września 1919 r. walczyła na froncie oneskim u boku wojsk francuskich i brytyjskich. Od 20 maja 1919 r. w walkach brała udział sformowana druga kompania strzelców oraz kompania karabinów maszynowych. W toku walk, w których uczestniczyli żołnierze Batalionu Murmańskiego, mjr Skokowski otrzymał awans na podpułkownika, natomiast ppłk Sołłohub na pułkownika sztabu generalnego. Ponadto żołnierze polscy otrzymali medale francuskie oraz angielskie.

\section{Powrót cywilnych reemigrantów przez Gdańsk}

Sytuacja na północnych kresach Rosji była daleka od stabilizacji. Opanowane przez wojska sprzymierzonych tereny nie spełniły swej roli jako miejsce koncentracji większej liczby Polaków chętnych do pełnienia służby wojskowej. Tworzące się oddziały wojskowe były doraźnie wykorzystywane do walk z bolszewikami, jednak docelowo miały zostać przetransportowane do Francji i włączone w skład armii polskiej. Zamiar ten został zrealizowany jedynie częściowo, w odniesieniu do kadry oficerskiej bez przydziałów, natomiast sformowane oddziały nie zostały ewakuowane do Francji. Po przetransportowaniu „Błękitnej Armii” do Polski w miesiącach wiosennych i letnich 1919 r. również murmańczycy zaczęli przygotowywać się do powrotu do kraju. Ich misja na północy Rosji została wypełniona, ponieważ ze względu na postępującą ofensywę bolszewicką w sierpniu 1919 r. dowództwo angielskie podjęło decyzję o ewakuacji sił sprzymierzonych z terenu północnej Rosji.

W pierwszej kolejności zajęto się ludnością cywilną, w tym liczną kolonią polską przebywającą w Archangielsku. Ewakuację Polaków zapewnił statek "Caritza": znajdujące się na jego pokładzie 724 osoby pochodzenia polskiego 28 sierpnia przybyły do Gdańska ${ }^{9}$. Był to pierwszy po zakończeniu I wojnyświatowej znaczący transport reemigrantów polskich przybyły do Gdańska.

${ }^{9}$ H. Bagiński, dz.cyt., s. 480; Z. Chrząstowski, dz.cyt., s. 191, 195, 202; Archiwum Państwowe Gdańsk [dalej: APG], Komisarz Generalny RP w Gdańsku, 259/30, Sprawozdanie ruchu remigracyjnego od d. 12.8 do 30.9.1919 r., k. 7-8. 
Funkcjonująca od 1 lutego 1919 r. w Gdańsku Delegacja Rządu Polskiego, afiliowana przy Interallied Relief Administration i kierowana przez Mieczysława Jałowieckiego, stanęła przed koniecznością zorganizowania w terminie zaledwie kilku dni, pobytu w mieście murmańczyków oraz wyekspediowania ich do Polski. Dodatkowo, jak się okazało, zaistniała konieczność przezwyciężenia oporu wciąż urzędujących w Gdańsku władz niemieckich, które początkowo odmówiły zgody na zejście na ląd reemigrantów i wysłanie ich do Polski, argumentując, że kwestia ta nie jest uregulowana w par. 16 warunków francusko-niemieckiego rozejmu podpisanego 11 listopada 1918 r. $^{10}$. Dopiero po trzech dniach, wskutek wielokrotnych interwencji w Berlinie, przedstawicieli Koalicyjnej Misji Żywnościowej w Gdańsku, władze gdańskie zezwoliły na wylądowanie reemigrantów i ich przejazd przez terytorium niemieckiego Pomorza do granicy państwa polskiego ${ }^{11}$.

Jak wspomniano wyżej, Jałowiecki został zaskoczony informacją o skierowaniu do Gdańska znaczącej grupy reemigrantów. Dotychczas jego podstawowym zadaniem było organizowanie transportów z amerykańską pomocą żywnościową przeznaczoną dla Polski. Już 18 lutego z Gdańska został wyekspediowany do Polski pierwszy pociąg (załadowany 17 lutego), natomiast 31 marca z portu wypłynęły drogą rzeczną cztery tzw. berlinki, czyli barki załadowane mąką. ${ }^{12}$ Po otrzymaniu wiadomości o spodziewanym zawinięciu do portu w Gdańsku „Caritzy” z murmańczykami na pokładzie Jałowiecki - nie pytając zwierzchników o zgodę - powołał do życia Wydział Reemigracji przy Delegacji Rządu Polskiego w Gdańsku, na czele którego mianował Czesława Raczewskiego. Jednocześnie zwrócił się do Polaków mieszkających w Gdańsku o pomoc w zapewnieniu opieki nad reemigrantami. W odpowiedzi powstał Komitet Opieki nad Reemigrantami, kierowany przez Antoninę Franciszkę Panecką. Współpracownicy Jałowieckiego pozyskali tzw. QuaranteneAnsalt, czyli baraki usytuowane w strefie wolnocłowej, gdzie można było umieścić

10 „XVI) Les Alliés auront libre accès aux territoires évacués par les Allemands, sur les frontières orientales, soit par Dantzig, soit par la Vistule, afin de pouvoir ravitailler les populations, et dans le but de maintenir l'ordre.'

11 APG 259/2, [M. Jałowiecki], Sprawozdanie z działalności Wydziału Reemigracyjnego [1920], k. 17-18.

12 APG 259/1055, Ruch towarów za czas od 14 lutego 1919 r. do 20-go grudnia 1920 r., k. 1-2. 
do 200 osób. Ze względu na ograniczone możliwości lokalowe najważniejsze zadanie polegało na zorganizowaniu transportu dla reemigrantów jeszcze w dniu ich zejścia na ląd. W Gdańsku każdy z nich otrzymywał posiłek oraz paczkę z żywnością na drogę (dzieci dodatkowo otrzymywały mleko) ${ }^{13}$.

Łącznie w okresie od sierpnia do końca listopada 1919 r. przez Gdańsk przewinęło się 2763 reemigrantów, którzy - z pominięciem uciążliwego pobytu w obozie przejściowym w Troylu - po wylądowaniu zostali przetransportowani do Polski ${ }^{14}$.

\section{Ewakuacja żołnierzy Oddziału Murmańskiego}

Niezwłocznie po powrocie 18 września z frontu do Archangielska, dnia 20 września, żołnierze Oddziału Murmańskiego opuścili Archangielsk na pokładzie statku „Toloa”, który 2 października zawinął do portu w Edynburgu. Żołnierze zostali zakwaterowani początkowo w hali „Olimpii”, a następnie w koszarach i na DreghornCastle. Pobyt w Edynburgu przedłużył się do prawie dwóch miesięcy. Jedną z przyczyn opóźnienia mógł być spór o przejazd przez Niemcy i Gdańsk żołnierzy polskich z bronią w ręku. Ostatecznie ustalono, że w trakcie podróży broń miała być ukryta, ale pozostawała dostępna dla żołnierzy ${ }^{15}$.

Batalion Murmański opuścił Edynburg w dniu 1 grudnia na pokładzie statku „Helena”. Współpasażerami na statku byli jeńcy niemieccy eskortowani przez żandarmów angielskich. Pierwotnie celem podróży był Gdańsk, jednak incydent, do którego doszło 3 grudnia w czasie postoju statku w Kilonii, spowodował zmianę trasy. Kilku spośród transportowanych przez Anglików jeńców zdołało wydostać się ze statku. Gdy w ślad za nimi na lądzie znalazł się uzbrojony patrol angielski, potraktowano to wydarzenie jako naruszenie prawa międzynarodowego. Nastąpiła eskalacja konfrontacji pomiędzy Niemcami i Koalicjantami: po jednej stronie stanęli wzburzeni jeńcy niemieccy oraz gromadzący się na lądzie tłum, po drugiej żandarmi angielscy, wspomagani przez żołnierzy polskich, którzy prawdopodobnie wyciągnęli ukrytą broń. W od-

13 APG 259/2, Sprawozdanie z działalności Wydziału Reemigracyjnego, k. 17-18.

14 APG 259/30 Sprawy emigracji i reemigracji, k. 49.

15 H. Bagiński, dz.cyt., s. 481; Żotnierz polski..., s. 52-53. 
powiedzi na sprowadzenie przez komendanta portu batalionu niemieckiego, który ustawił się z dwóch stron kanału i jednoczesne zamknięcie śluzy - z kolei komendant „Heleny” wezwał na pomoc dwa stojące na redzie pancerniki, francuski oraz angielski. Sytuacja wyglądała dramatycznie, jednak zakończyła się zawarciem kompromisu, na mocy którego wszyscy jeńcy niemieccy zostali wypuszczeni ze statku, a „Helena” mogła bez przeszkód kontynuować rejs po Morzu Bałtyckim. W tej sytuacji nastąpiła jednak zmiana trasy: żołnierze polscy następnego dnia (4 grudnia), po zawinięciu „Heleny” do portu w Szczecinie, opuścili statek i dalszą drogę do Polski odbyli pociągiem. W trakcie przeładowania ze statku na pociąg (4-5 grudnia) dworzec w Szczecinie otoczono „szerokim i gęstym kordonem [niemieckich] żołnierzy”. Dnia 6 grudnia Batalion Murmański odbył defiladę w Poznaniu przed gen. Józefem Dowborem-Muśnickim; jeszcze tego samego dnia żołnierze pojechali do Modlina ${ }^{16}$.

21 grudnia w Warszawie podczas obchodów 5 rocznicy powstania 5 pułku piechoty Legionów Polskich nastąpiła uroczysta prezentacja wojsk polskich przybyłych z Archangielska. Po nabożeństwie odprawionym przez kanclerza papieskiego ks. Jachimowicza w kościele garnizonowym, w którym uczestniczyli m.in.: gen. Haller, biskup polowy ks. Gall, generałowie, delegacje pułków, przedstawiciele Ententy oraz dawni murmańczycy - oficerowie „Błękitnej Armii”, na placu Saskim odbyła się defilada przyjęta przez Naczelnika Państwa Józefa Piłsudskiego ${ }^{17}$.

Po krótkim pobycie w Modlinie ewakuowani z północnej Rosji żołnierze Oddziału Murmańskiego zostali na początku 1920 r. wcieleni do Grudziądzkiego Pułku Strzelców, formowanego w Inowrocławiu. W skład odrębnego III batalionu, dowodzonego przez por. Bronisława Ducha, weszło 14 oficerów i 278 żołnierzy murmańczyków. 5 III 1920 r. jednostka została przemianowana na 64 Pułk Piechoty (od 1938 r. nosiła nazwę Pułku Strzelców Murmańskich) 16 Dywizji Pomorskiej. W maju 1920 r. żołnierze tegoż 64 Pułku wzięli

16 Tamże, s. 54.

17 W. Jędrzejewicz, J. Cisek, Kalendarium życia Józefa Piłsudskiego 1867-1935, t. II 1918-1926, Warszawa 1998, s. 151.Informacja, że uroczystości odbyły się 15 grudnia, podana w ślad za publikacją Żołnierz polski..., s. 55, nie jest potwierdzona przez źródła prasowe, np. „Kurier Poznański” nr 295, 23 XII 1919, który podaje, że msza św. i defilada odbyły się w niedzielę 21 grudnia. 
udział w walkach na froncie polsko-bolszewickim pod Czarnobylem, Zabinką, Opolem-Nowym (pod Siedlcami), Małorytą, Borkami i Dywinem ${ }^{18}$.

\section{Podsumowanie}

W trzech rozpoznanych źródłowo transportach drogą morską w 1919 r. żołnierzy polskich oraz cywilnych uchodźców z Archangielska i Murmańska statkami „Stephen”, „Caritza” i „Helena” - ewakuowano łącznie przynajmniej 1093 osoby, w tym 369 oficerów i szeregowców. Zważywszy, że Polacy opuszczali obszar północnej Rosji również w niewielkich grupach bądź pojedynczo, można oszacować, że ogólna liczba Polaków ewakuowanych w 1919 r. z tamtego rejonu przekroczyła 1,5 tys. osób. Dla porównania ewakuacja drogą morską do Gdańska Polaków z Dalekiego Wschodu w 1920 r. - statkami "Gweneth”, „Yaroslavl”, „Woroneż” i „Brandenburg” - objęła łącznie blisko 3,2 tys. osób, w tym 1744 oficerów i szeregowców ${ }^{19}$. Pojawienie się w Gdańsku 28 sierpnia 1919 r. statku „Caritza” z transportem 724 Polaków, zapoczątkowało serię znaczących transportów z reemigrantami przybywającymi nie tylko z objętej wojną domową Rosji, ale również ze Stanów Zjednoczonych, Wielkiej Brytanii i Danii. Pomimo występujących trudności, wynikających z ograniczenia praw polskich, port w Gdańsku stanowił w latach 1919-1920 najdogodniejsze miejsce do przyjmowania statków z powracającymi do kraju Polakami na pokładzie. O rozmiarach opisywanego zjawiska świadczą dane dotyczące okresu od sierpnia 1919 r. do 12 kwietnia 1920 r. - w Gdańsku przyjęto wówczas 9981 osób powracających statkami do Polski ${ }^{20}$. Wprawdzie kolejny statek „Helena” z żołnierzami polskimi ewakuowanymi z Archangielska ostatecznie zakończył swój rejs nie w Gdańsku, lecz w Szczecinie, jednak w 1920 r. do Gdańska przybyły, wspomniane wyżej, cztery zorganizowane transporty morskie z reemigrantami z Dalekiego Wschodu ${ }^{21}$. Gdańsk po zakończeniu I woj-

18 J. Krzyś, 64 Pomorski Pułk Strzelców Murmańskich, Pruszków 1993, s. 3-4; Żołnierz polski..., s. 55 .

19 W. Turek, Ewakuacja żołnierzy 5 Dywizji Syberyjskiej z Dalekiego Wschodu do Gdańska w 1920 r., [artykuł złożony do druku...].

${ }^{20}$ APG 259/2, Sprawozdanie z działalności Wydziału Reemigracyjnego, k. 18.

${ }^{21} \mathrm{~W}$ tym miejscu warto sprostować jako nieprawdziwą historię powrotu murmańczyków do Polski przez Gdańsk, opisaną przez Eugeniusza Małaczewskiego: „W Gdańsku 
ny światowej spełnił - w ograniczonym zakresie - rolę polskiego „okna na świat", aczkolwiek warto zaznaczyć, że realizacja powrotu żołnierzy polskich $\mathrm{z}$ dalekich stron przez miasto, będące przedmiotem ostrego polsko-niemieckiego sporu, nie została przez władze polskie wykorzystana dla wzmocnienia de facto polskiej pozycji w nadbałtyckim porcie. Nawiasem mówiąc, pomimo nadzwyczaj zawiłych negocjacji i rozlicznych kompromisów, problem militarnej obecności Polski w Gdańsku nie został rozwiązany w sposób pokojowy aż do tragicznego w skutkach wybuchu wojny 1 września 1939 r.

\section{BIBLIOGRAFIA}

\section{I. ŹRÓDEA}

Archiwum Państwowe w Gdańsku, Komisarz Generalny RP w Gdańsku, 259.

\section{Czasopisma}

„Kurier Poznański”.

\section{Dokumenty publikowane}

Jędrzejewicz W., Cisek J., Kalendarium życia Józefa Piłsudskiego 1867-1935, t. II 1918-1926, Warszawa 1998.

wylądowano bez szczególnych przygód, jeśli nie liczyć małego zajścia, wieczorem, w portowym szyneczku, które zostało wywołane prowokującą postawę żołdaków z „Grenzschutzu" wobec naszych zuchów. Zajście to jednak wnet zlikwidowali sami Murmańczycy, jąwszy się środków, o których znana piosenka lwowska śpiewa: »Nic nikomu nie mówili tylko w mordę bili, światła pogasili, Ta już, ta już !«”.

Baśka walnie spisała się $\mathrm{w}$ tej potrzebie, stając ramię w ramię z towarzyszami broni, i ona to w znacznej mierze przyczyniła się do przychylenia szali zwycięstwa na stronę polską. Przechodzi ludzkie pojęcie, jak ten inteligentny zwierz od razu, od pierwszego wejrzenia, znienawidził szwabów!

Nad ranem Oddział z bagażami i Baśką odjechał na wypoczynek do Modlina.

- Śmierdzi nam ten polski Gdańsk ! - zwierzali się sobie Murmańczycy z gdańskich wrażeń. - Niech jasny piorun trzaśnie w taki dostęp do morza i z powrotem. Widzieliście Anglików? Tyle już tam nawieźli swoich małpich konserw i jam- plum'u, że nam Gdańsk wkrótce obrócą w drugi Gibraltar”. E. Małaczewski, Dzieje Baśki Murmańskiej, Warszawa 1925. 


\section{Wspomnienia, pamiętniki}

Chrząstowski Z., Legenda murmańska, Łomianki 2014.

Małaczewski E., Dzieje Baśki Murmańskiej, Warszawa 1925.

Żołnierz polski na Murmanie: jednodniówka wydana z okazji pierwszego zjazdu murmańczyków: 1919 15/XII 1929, Warszawa 1929.

\section{OPRACOWANIA}

Bagiński H., Wojsko Polskie na Wschodzie 1914-1920, Warszawa 1921.

Encyklopedia Gdańska, red. B. Śliwiński [et al.], Gdańsk 2012.

Konopczyński W., Historia polityczna Polski 1914-1939, Warszawa 1995.

Krzyś J., 64 Pomorski Pułk Strzelców Murmańskich, Pruszków 1993.

Pajewski J., Odbudowa państwa polskiego 1914-1918, Warszawa 1985.

Turek W., Ewakuacja żotnierzy 5 Dywizji Syberyjskiej z Dalekiego Wschodu do Gdańska w 1920 r. [artykuł złożony do druku w: „Historia - Archiwa - Gdańsk”].

Wrzosek M., Polskie formacje wojskowe podczas pierwszej wojny światowej, Białystok, 1977. 